\title{
Metallomics
}

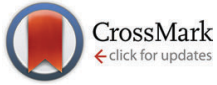

Cite this: Metallomics, 2014, 6, 2126

Received 10th September 2014 Accepted 3rd October 2014

DOI: 10.1039/c4mt00238e

www.rsc.org/metallomics

\section{Mechanisms of cell uptake and toxicity of the anticancer drug cisplatin}

\author{
Nasma D. Eljack, ${ }^{a}$ Ho-Yu M. Ma, ${ }^{a}$ Janine Drucker, ${ }^{b}$ Clara Shen, ${ }^{a}$ \\ Trevor W. Hambley, ${ }^{a}$ Elizabeth J. New, ${ }^{a}$ Thomas Friedrich ${ }^{b}$ and Ronald J. Clarke ${ }^{\star * a}$
}

Two major issues which hamper the use of the anticancer drug cisplatin are the development of cancer cell resistance and its nephrotoxicity. One possible mechanism by which resistance is reported to develop is a reduction in drug uptake across the cell membrane. While the passive uptake of cisplatin has long been cited as an important contribution, far greater attention has been given to active modes of uptake, particularly in recent research. Using unilamellar lipid vesicles together with the stopped-flow kinetic method we show here that the permeability coefficient of cisplatin increases significantly with the chloride concentration of the medium. This supports the hypothesis that cisplatin can enter cells via passive permeation through the lipid phase of the membrane, but becomes trapped within the cytoplasm because dissociation of chloride ligands yields a membrane-impermeant positively-charged aqua derivative. This is important evidence for a major role of passive membrane diffusion in the uptake of cisplatin, and suggests that reduced cell uptake is unlikely to be a significant mechanism leading to the development of drug resistance. Studies of rubidium ion uptake into the cytoplasm of Xenopus oocytes via the $\mathrm{Na}^{+}, \mathrm{K}^{+}$-ATPase show significant inhibition of this ion pump when cisplatin is present in the cytoplasm. Because $\mathrm{Na}^{+}, \mathrm{K}^{+}$-ATPase activity is essential to the survival of all animal cells, e.g. via maintenance of cell volume, and the $\mathrm{Na}^{+}, \mathrm{K}^{+}$-ATPase is expressed at particularly high levels within the membranes of kidney tubules where it plays a crucial role in nutrient reabsorption, these results suggest that cisplatin-induced inhibition of the $\mathrm{Na}^{+}, \mathrm{K}^{+}$-ATPase is a likely contributing cause for the nephrotoxicity of cisplatin.

\section{Introduction}

Cisplatin (cis-diamminedichloridoplatinum(II), cis-[ $\left.\mathrm{PtCl}_{2}\left(\mathrm{NH}_{3}\right)_{2}\right]$ ) can be considered one of the most effective chemotherapeutic agents, utilized for the treatment of a variety of solid human tumours. Once in the cytoplasm of a cell, it is well established that cisplatin undergoes a conversion to its aquated derivative cis-[PtCl( $\left.\left(\mathrm{NH}_{3}\right)_{2}\left(\mathrm{OH}_{2}\right)\right]^{+}$, driven by the approximately 13-fold lower concentration of chloride in the cell cytoplasm relative to the extracellular fluid. ${ }^{1,2}$ This aquated derivative is recognised to be responsible for the anti-cancer activity of the drug, because of its ability to react with DNA, eventually forming a bifunctional adduct which inhibits DNA replication and initiates cell apoptosis. ${ }^{3}$

Two major problems exist, however, in the clinical use of cisplatin. One is the development of tumour resistance to the drug during therapy, leading to treatment failure. ${ }^{4-7}$ The other is the drug's nephrotoxicity, which limits the dose that can be

\footnotetext{
${ }^{a}$ School of Chemistry, University of Sydney, NSW 2006, Australia.

E-mail: ronald.clarke@sydney.edu.au; Fax: +61-2-9351-3329; Tel: +61-2-9351-4406

${ }^{b}$ Institute of Chemistry, Sekr PC 14, Technical University of Berlin, Germany

$\dagger$ School of Chemistry, The University of Sydney, Rm 311, Building F11, NSW, 2006, Australia.
}

administered..$^{8}$ It is clear that much remains to be understood about the biophysical interactions of cisplatin with the cell membrane and with membrane-bound proteins.

Considering first the problem of resistance, at present the dominant mechanism accounting for clinically acquired resistance is still unknown. However, from experiments with cell lines to which cisplatin was administered at concentrations above the normal pharmacological level, a number of factors have been identified as contributing to resistance. ${ }^{4-7}$ At this stage, important mechanisms responsible for the development of cisplatin resistance appear likely to be: (1) decreased cytoplasmic accumulation of cisplatin, (2) increased levels of glutathione or glutathione-S-transferase activity, (3) increased levels of cytoplasmic metallothioneins, and (4) enhanced DNA repair. Here we will concentrate on the first of these possible mechanisms, i.e., decreased cytoplasmic accumulation of the drug. Assuming that the drug actually reaches the site of tumour cells, there are two possible origins for a decrease in the concentration of cisplatin within the tumour cell cytoplasm. One is a decrease in the kinetics of uptake of drug across the plasma membrane. The other is an increase in the rate of drug efflux, whether passive or active. To assess the feasibility that a decrease in drug uptake could contribute to 
the development of resistance, it is important to establish how cisplatin enters the cell.

The mechanism of cisplatin activity involving DNA binding of the metabolite cis-[PtCl$\left.\left(\mathrm{NH}_{3}\right)_{2}\left(\mathrm{OH}_{2}\right)\right]^{+}$, requires that an intact cisplatin molecule reaches the interior of the cell. Based on indirect evidence comparing protein expression levels to the amount of cellular Pt accumulated, it has been suggested that active uptake of cisplatin is mediated by membrane-embedded proteins including copper transporters, such as CTR1, ${ }^{9}$ or an organic cation transporter. ${ }^{10}$ Much recent attention in the search for new platinum complexes overcoming resistance or with increased potency has, therefore, focussed on these active transporters. However, there is increasing skepticism surrounding protein-mediated cisplatin uptake; recent studies showing irreversible binding of platinum to the cysteine-rich CTR1 protein ${ }^{11}$ suggest that it is unlikely that intact cisplatin can be transported into the cell via CTR1. ${ }^{12}$ Furthermore, Ivy and Kaplan ${ }^{13}$ recently reported no increase in the rate of cisplatin entry into a variety of cells on increasing the expression of CTR1. They also found that the rate of Pt drug uptake was not saturable, suggesting that it is not protein-mediated.

The structure of cisplatin is consistent with passive membrane diffusion; cisplatin has no net charge and therefore would not be subject to the huge Born energy barrier that prevents small hydrophilic ions from diffusing through the lipid phase of cell membranes. Hence, cisplatin could possibly enter tumour cells simply by passive diffusion through the lipid matrix of the membrane. To assess the feasibility of uptake by passive diffusion, here we report measurements of the permeability coefficient of cisplatin across the membranes of synthetic unilamellar lipid vesicles, i.e., a model membrane system in which proteins are entirely excluded. Because the plasma membrane of all animal cells is based on a lipid bilayer matrix, if cisplatin uptake does occur through the lipid matrix, then reduction in drug uptake is unlikely to be a means whereby resistance develops, because lipids are so intrinsic to membrane integrity that they can never be removed and any modification to the lipid composition is likely to have an adverse effect on membrane protein function.

The second important problem facing chemotherapy via cisplatin is the drug's nephrotoxicity. Recently it has been reported that cisplatin binds to a cytoplasmic-protruding domain of the $\mathrm{Na}^{+}, \mathrm{K}^{+}$-ATPase and inhibits the activity of the purified enzyme. ${ }^{14,15}$ As pointed out by Huličiak et al. ${ }^{14}$ the $\mathrm{Na}^{+}, \mathrm{K}^{+}$-ATPase is the only protein present in the plasma membrane of kidney tubule cells which generates the $\mathrm{Na}^{+}$ concentration gradient across the membrane, which provides the energy for driving all of the secondary active transporters responsible for the reabsorption of essential nutrients (e.g. glucose and amino acids) back into the bloodstream. Thus, if cisplatin causes a failure of the $\mathrm{Na}^{+}, \mathrm{K}^{+}$-ATPase this would lead to the collapse of the entire nutrient reabsorption machinery of the kidney. The $\mathrm{Na}^{+}, \mathrm{K}^{+}$-ATPase is hence a prime suspect in cisplatin's nephrotoxicity. Up to now, however, no tests of the effects of cisplatin on the $\mathrm{Na}^{+}, \mathrm{K}^{+}$-ATPase in intact cells have been carried out. Therefore, here we report the first measurements on the influence of cisplatin on the ion pumping activity of the $\mathrm{Na}^{+}, \mathrm{K}^{+}$-ATPase in a cell. For this purpose we have used Xenopus oocytes, because this system allows an over-expression of the protein and very precise measurements of ion uptake.

\section{Materials and methods}

\section{Materials}

1,2-Dioleoyl-sn-glycero-3-phosphocholine (99.9\%) was purchased from Sigma (Castle Hill, NSW, Australia). Tris[hydroxymethyl]aminomethane (Tris, 99.9\%) and $\mathrm{NaCl}$ (99.9\%) were from Sigma and Merck (Darmstadt, Germany), respectively. The purities and origins of the solvents used were as follows: chloroform (99.8\%, Fluka, Castle Hill, NSW, Australia) and methanol (99.8\%, EM Science, Gibbstown, NJ, USA). Cisplatin (cis-diamminedichloridoplatinum(II), cis-[ $\left.\left.\mathrm{PtCl}_{2}\left(\mathrm{NH}_{3}\right)_{2}\right]\right)$ was synthesized as described previously. ${ }^{16}$

\section{Preparation of unilamellar lipid vesicles and size determination}

To prepare unilamellar vesicles, $1 \mathrm{~mL}$ of a $0.1 \mathrm{mM}$ solution of dioleoylphosphatidylcholine (DOPC) in 9/1 v/v chloroform/ methanol was first evaporated with gentle rotation in a $25 \mathrm{~mL}$ round-bottom flask under reduced pressure at room temperature over 15 minutes using a rotary evaporator. The resultant lipid film was hydrated by adding $1.0 \mathrm{~mL}$ of a $5 \mathrm{mM}$ Tris buffer solution ( $\mathrm{pH} 7.4$ ) containing $\mathrm{NaCl}$ (concentrations in the range 10-150 mM) and occasional shaking over a 30 minute period. The multilamellar vesicle suspension thus formed was extruded through a $0.2 \mu \mathrm{m}$ Nucleopore polycarbonate filter 15 times at room temperature using an Avanti Mini-Extruder (Alabaster, AL, USA) to obtain the unilamellar vesicle suspension used for the cisplatin permeability measurements.

The mean vesicle radius of each vesicle preparation was measured via the dynamic light scattering method using a Nano Zetasizer (Malvern Instruments, Malvern, UK). Prior to each measurement of size, the vesicle suspension was diluted 100-fold. The dilutions were performed using the same buffer solution used in the vesicle preparation to avoid any swelling or shrinkage due to osmotic effects.

\section{Cisplatin permeability coefficient measurements}

The kinetics of cisplatin permeation through the membrane of the vesicles was measured by rapidly mixing a $3.3 \mathrm{mM}$ cisplatin solution in Tris buffer with an equal volume of lipid vesicle suspension in the same Tris buffer solution using an SF-61SX2/ s stopped-flow spectrometer (TgK Scientific, Bradford-on-Avon, UK). Changes in light scattering of the vesicle suspensions accompanying movement of water and cisplatin across the vesicle membrane were detected by monitoring the scattered light intensity at $90^{\circ}$ to the incident light beam. The wavelength of the incident light was $450 \mathrm{~nm}$. A $75 \mathrm{~W} \mathrm{Hg}$-Xe arc lamp (Hamamatsu Photonics, Hamamatsu City, Japan) was used as the light source and an R928 side-on photomultiplier (Hamamatsu Photonics) was used to detect the intensity of the scattered light. The $3.3 \mathrm{mM}$ cisplatin solutions were prepared by dilution from $5 \mathrm{mM}$ stock solutions which were prepared on the day before the 
stopped-flow measurements to allow sufficient time for ligand exchange to equilibrate.

At short times $(<0.1 \mathrm{~s}$ after mixing) there is a rapid increase in light scattering due to water efflux from the vesicles. This occurs because the external is hypertonic relatively to the intravesicular solution. At longer times (seconds to tens of seconds) there is a slower drop in light scattering again as cisplatin diffuses into the vesicles accompanied by water. Similar behaviour has been observed for the passive diffusion of many other solutes across the membranes of vesicles in the past. ${ }^{17,18}$ Only the slow drop in light scattering has been analysed here to determine the cisplatin permeability coefficient.

Measurements were performed for vesicle suspensions and cisplatin solutions prepared in buffer solutions containing $\mathrm{NaCl}$ concentrations varying from $10 \mathrm{mM}$ to $150 \mathrm{mM}$. For each $\mathrm{NaCl}$ concentration three to five kinetic traces were averaged and the observed rate constant, $k_{\text {obs }}$, was determined by fitting a single exponential time function to the averaged trace. The apparent cisplatin permeability coefficient, $P_{\mathrm{d}}$, for each $\mathrm{NaCl}$ concentration was then determined using the following equation:

$$
P_{\mathrm{d}}=\frac{k_{\mathrm{obs}} r}{3}
$$

where $r$ is the average radius of the vesicles, as determined by dynamic light scattering (see above). The multiplication of $k_{\mathrm{obs}}$ by the factor $r / 3$ comes about from the ratio of the volume of the vesicle to its surface area. ${ }^{17,18}$ Small vesicles with small surface areas allow faster equilibration of the osmotic conditions between the intra- and extra-vesicular spaces. The factor $r / 3$ accounts for this effect, and allows the vesicle-size-independent permeability coefficient to be determined.

\section{Over-expression of the $\mathrm{Na}^{+}, \mathrm{K}^{+}$-ATPase in Xenopus oocyctes}

Individual oocytes were isolated enzymatically from ovarian tissue of female Xenopus laevis frogs as described previously. ${ }^{19}$ The cDNAs of human $\mathrm{Na}^{+}, \mathrm{K}^{+}$-ATPase $\alpha 2$ - and $\beta 1$-subunit were subcloned into an appropriate expression vector (pcDNA3.1X). ${ }^{20}$ To distinguish the activity of the overexpressed human $\mathrm{Na}^{+}, \mathrm{K}^{+}$ATPase from the endogenous $\mathrm{Na}^{+}, \mathrm{K}^{+}$-ATPase of the oocytes, the mutations Q116R and N127D were introduced into the $\alpha 2$-subunit to obtain an ouabain-resistant protein with an IC50 in the millimolar range. ${ }^{21}$ This protein $(\alpha 2-Q 116 R / N 127 D$ plus $\beta 1$ ) is referred to as "RD-WT" throughout the text. After linearization of the plasmids, cRNA was synthesized in vitro using the T7 mMessage mMachine Kit (Ambion). For expression of the RD-WT enzyme, oocytes were injected with $50 \mathrm{~nL}$ cRNA solution containing $25 \mathrm{ng} \alpha 2$-subunit and $5 \mathrm{ng} \beta 1$-subunit cRNA using an electrically driven Nanoject II injection pump (Drummond Scientific Inc., Broomall, PA). To allow for functional measurements of $\mathrm{Na}^{+}, \mathrm{K}^{+}$-ATPase pumping activity, a $\mathrm{Na}^{+}$loading procedure was applied to elevate the intracellular $\mathrm{Na}^{+}$concentration. For this purpose, RD-WT-expressing oocytes were incubated for $45 \mathrm{~min}$ in $\mathrm{Na}^{+}$loading buffer $(110 \mathrm{mM} \mathrm{NaCl}, 2.5 \mathrm{mM}$ Na-citrate, $2.5 \mathrm{mM}$ MOPS, $2.5 \mathrm{mM}$ TRIS, $\mathrm{pH}$ 7.4) on ice, followed by 30 minutes recovery on ice in Post Loading Buffer (PLB: $100 \mathrm{mM} \mathrm{NaCl}, 1 \mathrm{mM}$ $\mathrm{CaCl}_{2}, 5 \mathrm{mM} \mathrm{BaCl}_{2}, 5 \mathrm{mM} \mathrm{NiCl}_{2}$ and $2.5 \mathrm{mM}$ MOPS, $2.5 \mathrm{mM}$ TRIS,
$\mathrm{pH}$ 7.4). Oocytes were stored in PLB on ice until use. Endogenous $\mathrm{Na}^{+}, \mathrm{K}^{+}$-ATPase expressed by the oocytes was blocked before carrying out $\mathrm{Rb}^{+}$uptake measurements by incubating the oocytes for $15 \mathrm{~min}$ at room temperature with a buffer containing $100 \mu \mathrm{M}$ of ouabain, a specific inhibitor of the $\mathrm{Na}^{+}, \mathrm{K}^{+}$-ATPase. During flux measurements, all buffers contained $10 \mu \mathrm{M}$ ouabain.

\section{Atomic absorption measurements of rubidium uptake}

For $\mathrm{Rb}^{+}$uptake studies, $\mathrm{Na}^{+}$-loaded and preincubated oocytes were transferred into a petri dish filled with $\mathrm{Rb}^{+}$flux buffer $(100 \mathrm{mM}$ $\mathrm{NaCl}, 5 \mathrm{mM} \mathrm{BaCl}_{2}, 2 \mathrm{mM} \mathrm{MgCl}_{2}, 2.5 \mathrm{mM}$ MOPS, $2.5 \mathrm{mM}$ TRIS, $1 \mathrm{mM} \mathrm{CaCl}_{2}, 10 \mu \mathrm{M}$ Ouabain, $\mathrm{pH}$ 7.4, plus RbCl in concentrations from 0 to $15 \mathrm{mM}$ ) and incubated for exactly 3 min under temperature control $\left(21{ }^{\circ} \mathrm{C}\right.$ in an air-conditioned room). Subsequently, oocytes were washed three times in $\mathrm{Rb}^{+}$-free PLB buffer and then transferred to a Petri dish filled with Millipore water. Afterwards, individual cells are transferred into Eppendorf tubes filled with $1 \mathrm{~mL}$ Millipore water and homogenized using a narrowgauge pipette $(200 \mu \mathrm{L})$. From these probes (which can be stored at $-20{ }^{\circ} \mathrm{C}$ until analysis with atomic absorption spectrophotometry (AAS)), $20 \mu \mathrm{L}$ were transferred by an autosampler into the transversally heated graphite atomizer (THGA) furnace of the AAS instrument (Perkin Elmer AAnalyst 800), which was equipped with an appropriate $\mathrm{Rb}$ hollow cathode lamp. For each measuring condition (e.g. $\mathrm{Rb}^{+}$concentration) at least 10 oocytes from at least two independent cell preparations were included in analysis. Data are presented as means \pm standard error.

\section{Rubidium uptake in the presence of activated intracellular cisplatin}

Since experiments on purified $\mathrm{Na}^{+}, \mathrm{K}^{+}$-ATPase as reported by Huličiak et al. ${ }^{14}$ indicated that about $50 \%$ maximal inhibition of ATPase activity is achieved at concentrations of activated cisplatin (cis-diammineaquochlorido platinum(II)) above $4 \mu \mathrm{M}$, we wanted to establish conditions that allow a defined intracellular concentration of activated cisplatin to be achieved. For this purpose, cisplatin (Sigma-Aldrich, Munich, Germany) was dissolved in Millipore water at a concentration of $1 \mathrm{mM}$ and incubated for $24 \mathrm{~h}$ at $4{ }^{\circ} \mathrm{C}$ in the dark to allow for the formation of the activated complexes. $50 \mathrm{~nL}$ of the $1 \mathrm{mM}$ activated cisplatin solution was injected into RD-WT expressing oocytes followed by a $1 \mathrm{~h}$ incubation time on ice in $\mathrm{Rb}^{+}$-free PLB solution to allow for oocyte resealing and equilibration of the compound within the intracellular space. Since oocytes typically have between 1 and $1.5 \mathrm{~mm}$ diameter, the injection of $50 \mathrm{~nL}$ of $1 \mathrm{mM}$ activated cisplatin should create an intracellular concentration between 25 and $100 \mu \mathrm{M}$. Cisplatin-injected oocytes were compared with non-treated cells from the same preparation.

\section{Results and discussion}

Kinetics of cisplatin diffusion across the lipid vesicle membrane

On mixing DOPC vesicles with a Tris buffer solution containing cisplatin there is initially a rapid increase in light scattering of 


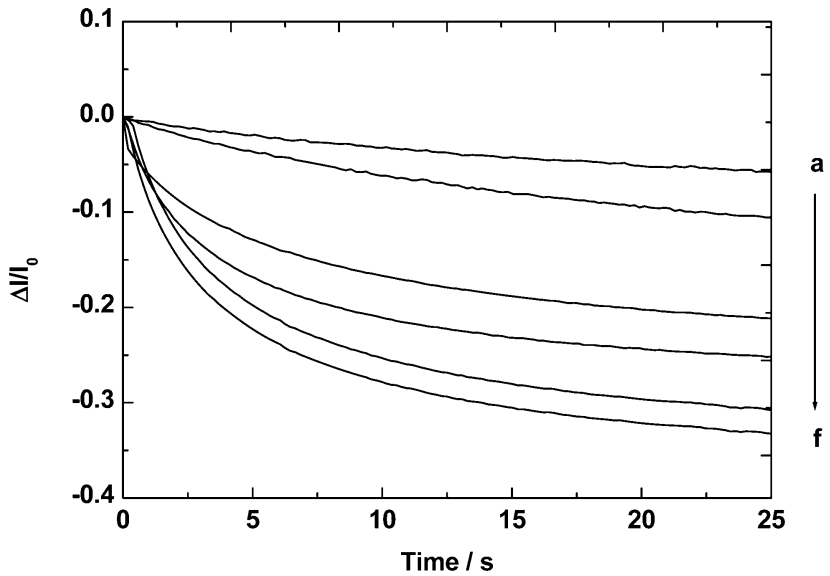

Fig. 1 Kinetics of cisplatin diffusion across the membrane of DOPC vesicles. The kinetic traces show the change in relative light intensity, $\Delta / / I_{0}$, observed on mixing of $3.3 \mathrm{mM}$ cisplatin in $5 \mathrm{mM}$ Tris buffer with an equal volume of $5 \mathrm{mM}$ Tris buffer containing different concentrations of $\mathrm{NaCl}$. After fitting to single exponential time functions curves a-f were found to be described by the following $k_{\text {obs }}$ values with the corresponding $\mathrm{NaCl}$ concentrations in brackets: $0.020( \pm 0.002) \mathrm{s}^{-1}(10 \mathrm{mM}), 0.075$ $( \pm 0.003) \mathrm{s}^{-1}(50 \mathrm{mM}), 0.129( \pm 0.002) \mathrm{s}^{-1}(75 \mathrm{mM}), 0.203( \pm 0.004) \mathrm{s}^{-1}$ (100 mM), $0.210( \pm 0.003) \mathrm{s}^{-1}(125 \mathrm{mM})$ and $0.210( \pm 0.004) \mathrm{s}^{-1}(150 \mathrm{mM})$. The temperature was $25^{\circ} \mathrm{C}$ and the $\mathrm{pH}$ was 7.4 .

the sample due to the efflux of water from the vesicles (see Materials and methods) followed by a slower decrease in scattering (see Fig. 1) which is attributed to the diffusion of cisplatin into the intravesicular space accompanied by water. As can be seen from the traces shown in Fig. 1, the kinetics of the slow drop in light intensity is strongly dependent on the concentration of $\mathrm{NaCl}$ present in the buffer, i.e., the passive diffusion of cisplatin across the membrane appears to be significantly slower at low $\mathrm{NaCl}$ concentrations.

However, to compare the kinetics of cisplatin diffusion at different $\mathrm{NaCl}$ concentrations one must also take into account the size of the vesicles, which can vary slightly from one preparation to another, via eqn (1) (see Materials and methods). Combining the observed rate constants, $k_{\text {obs }}$, obtained by the fitting of single exponential time functions to the curves shown in Fig. 1 with the mean vesicle radii of each vesicle preparation at each $\mathrm{NaCl}$ concentration according to eqn (1) yields the permeability coefficient, $P_{\mathrm{d}}$, of the vesicles towards cisplatin. The dependence of the observed value of $P_{\mathrm{d}}$ as a function of the chloride concentration in the buffer is shown in Fig. 2. There it can be seen that $P_{\mathrm{d}}$ increases steadily as the chloride concentration of the buffer increases until a saturating value of approximately $1.1 \times 10^{-6} \mathrm{~cm} \mathrm{~s}^{-1}$ is reached at a $\mathrm{Cl}^{-}$concentration of approximately $100 \mathrm{mM}$.

The much lower permeability coefficient at low chloride concentrations can be explained by the dependence of the stability of the cisplatin complex on the concentration of chloride in the surrounding medium. The chloride ligands of the complex are labile and can be easily replaced by $\mathrm{H}_{2} \mathrm{O}$ ligands when the chloride concentration of the surroundings drops. At a chloride concentration of $110 \mathrm{mM}$, corresponding to a physiological extracellular chloride concentration, it has been

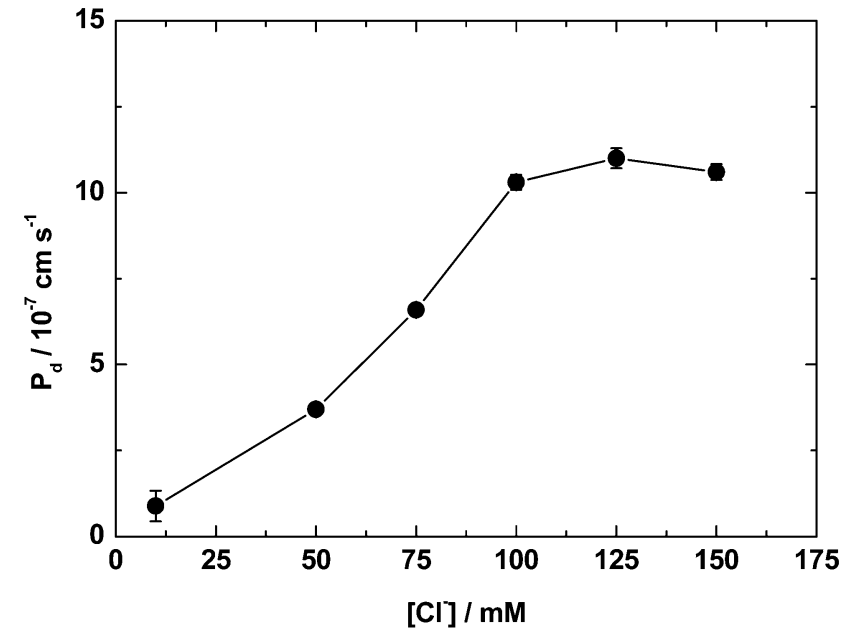

Fig. 2 Apparent permeability coefficient, $P_{\mathrm{d}}$, of cisplatin towards the membrane of DOPC vesicles as a function of the chloride concentration in the buffer solution. The $P_{\mathrm{d}}$ values were calculated from eqn (1) using the $k_{\text {obs }}$ values of the stopped-flow kinetic traces shown in Fig. 1 and average vesicle radii determined from dynamic light scattering measurements: $134( \pm 2) \mathrm{nm}(10 \mathrm{mM}), 148( \pm 1) \mathrm{nm}(50 \mathrm{mM}), 153( \pm 2) \mathrm{nm}(75 \mathrm{mM})$, $152( \pm 2) \mathrm{nm}(100 \mathrm{mM}), 157( \pm 3) \mathrm{nm}(125 \mathrm{mM})$ and $151( \pm 3) \mathrm{nm}(150 \mathrm{mM})$.

calculated that $85 \%$ of the drug is present in the dichlorido form, with $11 \%$ in the chloridohydroxido form and $4 \%$ in the chloridoaqua form..$^{22-24}$ Thus, $96 \%$ of the drug would be expected to have an overall neutral charge at a chloride concentration of $110 \mathrm{mM}$. The neutral charge would facilitate diffusion of the drug through the nonpolar interior of the lipid bilayer. However, at low chloride concentrations, such as those present in the cytoplasm of a cell, where the concentration is typically only around $4 \mathrm{mM}$, a much higher percentage of charged forms would be expected, such as $\left[\mathrm{Pt}\left(\mathrm{NH}_{3}\right)_{2}\left(\mathrm{H}_{2} \mathrm{O}\right)_{2}\right]^{2+}$. The positive charge would be expected to significantly reduce the ability of the drug to pass through the membrane, in agreement with the much lower $P_{\mathrm{d}}$ values observed at low chloride concentrations (see Fig. 2).

In addition to the slow diffusion of positively charged cisplatin derivatives out of the cell, once they have been formed within the cytoplasm their concentration in the cytoplasm relative to the extracellular medium would be expected to be further enhanced by the Donnan effect. ${ }^{25}$ This is due to the prevalence of negatively over positively charged impermeable macromolecules within the cell cytoplasm, e.g. DNA and proteins, which causes an electrostatic attraction for cations in order to maintain electroneutrality within the cytoplasm. Thus, all cations which have any permeability towards the membrane, with the exception of $\mathrm{Na}^{+}$(which is actively pumped out by the $\mathrm{Na}^{+}, \mathrm{K}^{+}$ATPase), display a concentration gradient across the cell membrane with a higher concentration in the cytoplasm relative to the extracellular fluid. In the absence of any active pumping mechanisms, an ion's concentration distribution across the membrane is determined by the electrical membrane potential and is given by the Nernst equation.

It has in fact been reported that the accumulation of cisplatin within the cell cytoplasm is dependent on the magnitude of the 
membrane potential, ${ }^{26}$ and this observation has sometimes been presented as evidence that transport of cisplatin into the cell is protein-mediated. ${ }^{27}$ However, as just described, the distribution of any ion which can passively permeate the plasma membrane is expected to be dependent on the membrane potential. If uptake was entirely passive, in its uncharged $\left[\mathrm{PtCl}_{2}\left(\mathrm{NH}_{3}\right)_{2}\right]$ form no dependence on the membrane potential would be expected, but as soon as cisplatin enters the cytoplasm and loses its labile chloride ions to become positively charged a membrane potential dependence would become apparent. The accumulation of $\left[\mathrm{Pt}\left(\mathrm{NH}_{3}\right)_{2}\left(\mathrm{OH}_{2}\right)_{2}\right]^{2+}$ or $\left[\mathrm{PtCl}\left(\mathrm{NH}_{3}\right)_{2}\left(\mathrm{OH}_{2}\right)\right]^{+}$within the cytoplasm would be inhibited by an increase in the membrane potential, i.e., positive in the cytoplasm. This could explain the observation that cisplatin accumulation within the cytoplasm is inhibited on addition of the specific $\mathrm{Na}^{+}, \mathrm{K}^{+}$-ATPase inhibitor ouabain. ${ }^{28}$ The $\mathrm{Na}^{+}, \mathrm{K}^{+}$-ATPase controls the $\mathrm{Na}^{+}$and $\mathrm{K}^{+}$distributions across the plasma membrane and hence indirectly the membrane potential. If it is inhibited by ouabain, $\mathrm{Na}^{+}$would flow into the cell to take up its equilibrium distribution in accord with the Donnan effect and the membrane potential would become slightly more positive. The increase in positive charge within the cytoplasm would disfavour accumulation of $\left[\mathrm{Pt}\left(\mathrm{NH}_{3}\right)_{2}\left(\mathrm{H}_{2} \mathrm{O}\right)_{2}\right]^{2+}$ or $\left[\mathrm{PtCl}\left(\mathrm{NH}_{3}\right)_{2}\left(\mathrm{OH}_{2}\right)\right]^{+}$, i.e. consistent with experimental results. Similarly, metabolic inhibitors which would decrease the production of ATP and hence its supply to the $\mathrm{Na}^{+}, \mathrm{K}^{+}$-ATPase would be expected to decrease accumulation of $\left[\mathrm{Pt}\left(\mathrm{NH}_{3}\right)_{2}\left(\mathrm{H}_{2} \mathrm{O}\right)_{2}\right]^{2+}$ or $\left[\mathrm{PtCl}\left(\mathrm{NH}_{3}\right)_{2}\left(\mathrm{OH}_{2}\right)\right]^{+}$within the cytoplasm, as experimentally observed. ${ }^{28}$ Such results have also been previously presented as evidence for protein-mediated uptake of cisplatin, ${ }^{27}$ but are in fact consistent with passive diffusion across the membrane.

Another important piece of evidence pointing to a passive uptake mechanism of cisplatin is the fact that the uptake of cisplatin is linear with its concentration even up to its solubility limit, i.e., no saturation is observable. ${ }^{13,29}$ Finally, structural analogues of cisplatin have been found to cause no inhibition of cisplatin uptake, contrary to what one would expect if an active protein-mediated uptake mechanism was involved. ${ }^{30}$ These observations, as well as our own data presented here, therefore, are all consistent with the recent re-evaluation of platinum-drug entry by Ivy and $\operatorname{Kaplan}^{13}$ that the process occurs via a mechanism of solubility diffusion through the membrane.

\section{Rubidium uptake by human $\mathrm{Na}^{+}, \mathrm{K}^{+}$-ATPase into Xenopus oocytes in the presence and absence of activated cisplatin}

In its normal mode of function, the $\mathrm{Na}^{+}, \mathrm{K}^{+}$-ATPase utilises the energy released from ATP hydrolysis to actively transport $\mathrm{Na}^{+}$ out of the cell and $\mathrm{K}^{+}$in. Although the $\mathrm{Na}^{+}$transport is very specific, a number of ions can act as congeners replacing $\mathrm{K}^{+}$, including $\mathrm{Rb}^{+}{ }^{31}$ Thus, measurements of the kinetics of uptake of $\mathrm{Rb}^{+}$by a cell allows one to assess the activity of the $\mathrm{Na}^{+}, \mathrm{K}^{+}$ATPase and to identify any inhibitory effects of drugs, such as cisplatin. Measuring $\mathrm{Rb}^{+}$uptake has advantages over measuring the physiological substrate $\mathrm{K}^{+}$. Firstly, prior to any $\mathrm{Rb}^{+}$ uptake the concentration of $\mathrm{Rb}^{+}$inside the cell is negligible and hence there is no background that needs to be subtracted. Secondly, hollow cathode lamps for $\mathrm{Rb}^{+}$are available, which allow the $\mathrm{Rb}^{+}$level in the cell cytoplasm to be quantified with high sensitivity and precision via atomic absorption spectrophotometry. Due to the high intracellular background of $\mathrm{K}^{+}$, the procedure can't be performed in the case of $\mathrm{K}^{+}$.

The effect of the rubidium concentration on the $\mathrm{Na}^{+}, \mathrm{K}^{+}$ATPase-mediated uptake of rubidium ions after 3 minutes incubation time is shown in Fig. 3. The data in Fig. 3 (upper panel) show that $\mathrm{Rb}^{+}$uptake by the heterologously expressed RD-WT enzyme is drastically inhibited by $10 \mathrm{mM}$ ouabain, a specific inhibitor of the $\mathrm{Na}^{+}, \mathrm{K}^{+}$-ATPase. Although inhibition at $10 \mathrm{mM}$ ouabain is not complete (due to the competition of $\mathrm{Rb}^{+}$ and ouabain for binding to the $\mathrm{E} 2$ form of the enzyme), the data indicate that the uptake is indeed specifically due to the human $\mathrm{RD}-\mathrm{WT} \mathrm{Na}^{+}, \mathrm{K}^{+}$-ATPase and not to any other transporter.
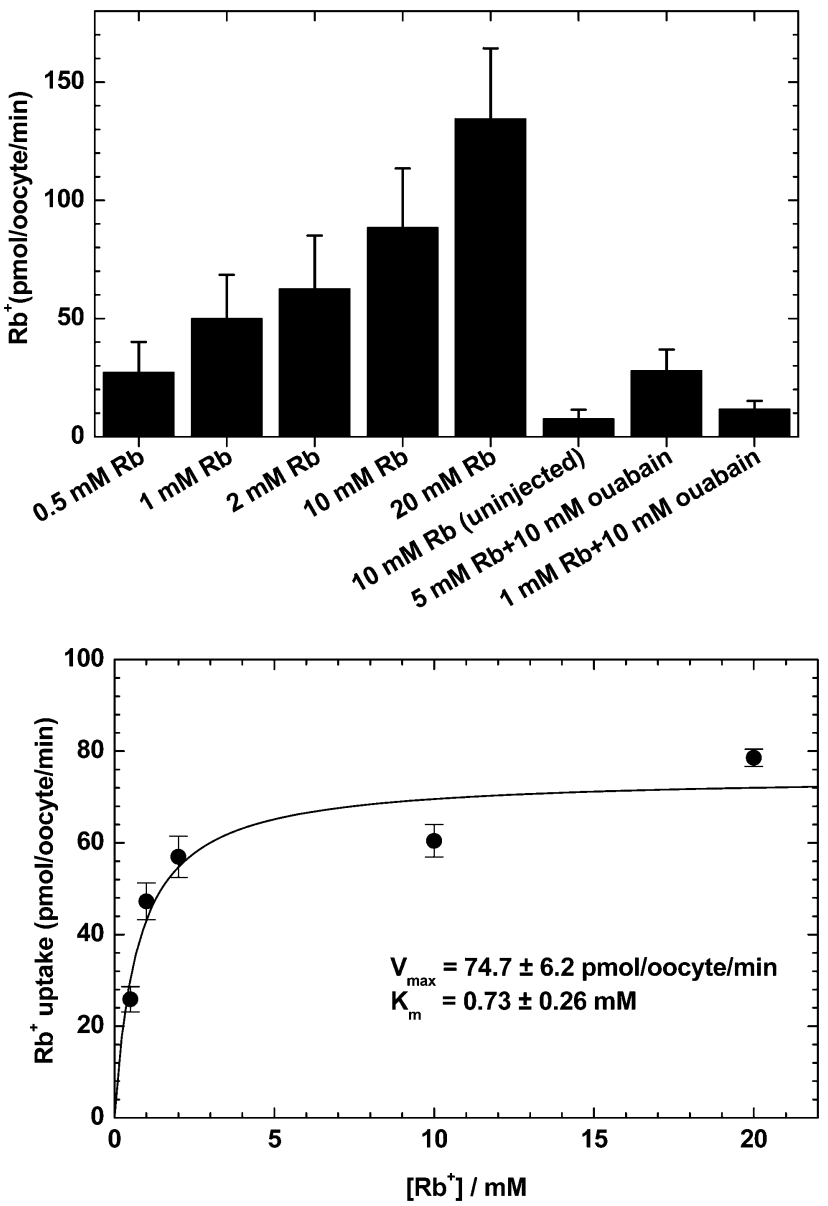

Fig. $3 \mathrm{Rb}^{+}$uptake into RD-WT-expressing Xenopus oocytes. The upper panel shows the concentration-dependent $\mathrm{Rb}^{+}$uptake (in picomoles per oocyte per minute) by human RD-WT $\mathrm{Na}^{+}, \mathrm{K}^{+}$-ATPase in the presence of $100 \mathrm{mM}$ extracellular $\mathrm{Na}^{+}$. The specificity of the signal for the RD-WT enzyme is demonstrated by the substantial inhibition of $\mathrm{Rb}^{+}$uptake by $10 \mathrm{mM}$ ouabain. The level of passive $\mathrm{Rb}^{+}$uptake into uninjected control oocytes of the same batch is shown by column 6 from left. Lower panel: fit of a Michaelis-Menten-type function to the data from columns 1-5 from left panel yields a $K_{M}$ value of $0.73( \pm 0.26) \mathrm{mM}$. Data are given as means \pm S.E. with 18-24 cells from three different cell preparations. 
The significant increase in $\mathrm{Rb}^{+}$uptake with increasing $\mathrm{Rb}^{+}$ concentration indicates that under the conditions of the experiments shown in Fig. 3, i.e., over the $\mathrm{Rb}^{+}$concentration range $0.5-20 \mathrm{mM}$ and the absence of any $\mathrm{K}^{+}$in the extracellular solution, the $\mathrm{Rb}^{+}$uptake arm of the enzyme's reaction cycle is a rate-limiting step for the overall turnover. Therefore, in order to test for any effect of a drug on $\mathrm{Rb}^{+}$uptake by the $\mathrm{Na}^{+}, \mathrm{K}^{+}$-ATPase, it is important to keep the $\mathrm{Rb}^{+}$concentration in this range and not to go to higher concentrations where $\mathrm{Rb}^{+}$could reach a saturating level. Fitting the $\mathrm{Rb}^{+}$uptake data (Fig. 3, lower panel) with a Michaelis-Menten-type function yields a $K_{\mathrm{M}}$ value for $\mathrm{Rb}^{+}$-stimulated $\mathrm{Rb}^{+}$uptake of $2.06( \pm 0.92) \mathrm{mM}$. However, as determined from independent control experiments on noninjected oocytes, a 3 min incubation in $\mathrm{Rb}^{+}$flux buffers leads to some non-specific $\mathrm{Rb}^{+}$uptake, which increases linearly with $\left[\mathrm{Rb}^{+}\right]$and is presumably due to passive diffusion through cation channels present in the oocyte membrane (the passive $\mathrm{Rb}^{+}$

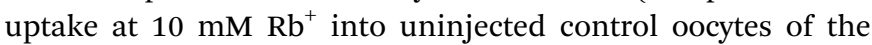
same batch is shown as column 6 from left in Fig. 3, upper panel). This non-specific $\mathrm{Rb}^{+}$uptake reaches about $20 \%$ of the specific (i.e. ouabain-sensitive) $\mathrm{Rb}^{+}$uptake signal at $20 \mathrm{mM} \mathrm{Rb}$ (data not shown). If the data are corrected for this non-specific uptake by linear interpolation (Fig. 3, lower panel), the resulting $K_{\mathrm{M}}$ value is $0.73( \pm 0.26) \mathrm{mM}$, which agrees well with data in the literature. $^{32}$

The effect on RD-WT-mediated $\mathrm{Rb}^{+}$uptake of the injection of $50 \mu \mathrm{M}$ pre-activated cisplatin into the cytoplasm of the oocytes prior to the addition of extracellular $\mathrm{Rb}^{+}$is shown in Fig. 4. There, it can be seen that activated cisplatin causes a significant (about $40-50 \%$ ) reduction in $\mathrm{Rb}^{+}$uptake, indicating a cisplatininduced inhibition of the $\mathrm{Na}^{+}, \mathrm{K}^{+}$-ATPase, with cisplatin acting on the cytoplasmic face of the enzyme. This is the first direct

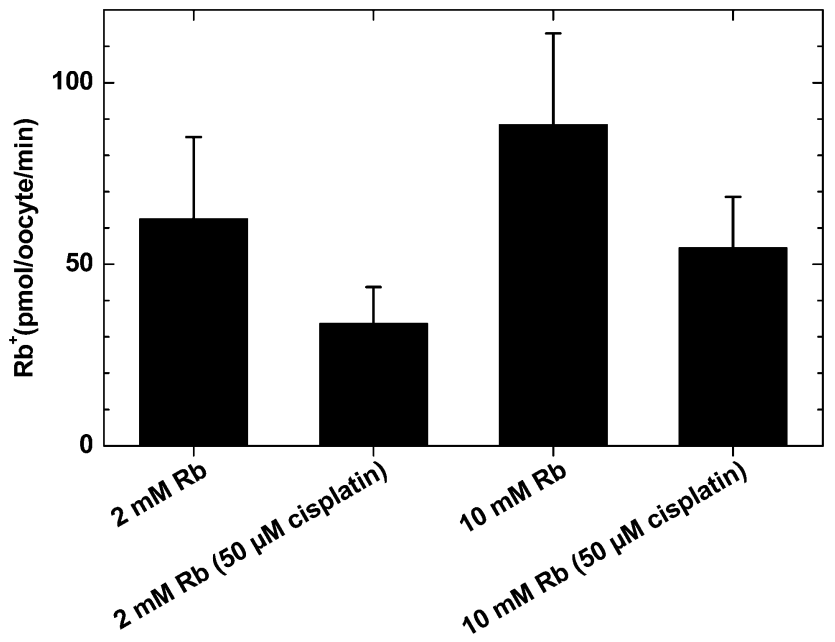

Fig. 4 Cisplatin inhibition of the human RD-WT $\mathrm{Na}^{+}, \mathrm{K}^{+}-\mathrm{ATPase}$. Prior to flux experiments $50 \mathrm{~nL}$ of a $1 \mathrm{mM}$ aqueous solution of activated cisplatin were injected into a subset of RD-WT-expressing cells, yielding an intracellular cisplatin concentration between about 25 to $100 \mu \mathrm{M}$. Compared to cells that were not treated with cisplatin, the $\mathrm{Rb}^{+}$uptake (in picomoles per oocyte per minute) at $2 \mathrm{mM}$ and $10 \mathrm{mM}$ extracellular $\mathrm{Rb}^{+}$is reduced by $47 \%$ or $39 \%$, respectively. Data are given as means \pm S.E. with $16-39$ cells from four different cell preparations. evidence for cisplatin-induced inhibition of the $\mathrm{Na}^{+}, \mathrm{K}^{+}$-ATPase in an intact cellular system. However, our data is entirely consistent with previously published findings obtained using isolated enzyme fractions of the $\mathrm{Na}^{+}, \mathrm{K}^{+}$-ATPase. ${ }^{14,15}$

The large intracellular loop (loop C45 as termed by Huličiak et $a l^{14}$ ) of the $\mathrm{Na}^{+}, \mathrm{K}^{+}$-ATPase $\alpha$ subunit contains 12 conserved cysteines, which are putative interaction sites of the compound according to the data of Huličiak et al. ${ }^{14}$ From MALDI-TOF peptide mass fingerprinting experiments, these authors suggested that the highly conserved Cys-367 in the immediate vicinity of the critical Asp-369, which is intermediately phosphorylated during the ATP hydrolysis cycle of the enzyme, might be a critical interaction site. However, this suggestion was not confirmed by a recent crystal structure of the $\mathrm{Na}^{+}, \mathrm{K}^{+}$-ATPase with bound cisplatin from the same group. ${ }^{33}$ The crystal structure enabled seven cisplatin binding sites to be identified. Of these, the most likely interactions which could lead to inhibition were considered to be with Met-151, which could block the N-terminal pathway for the transported ions, or with Met-171, which could hinder interaction between cytoplasmic domains during the catalytic cycle. The data presented here set the stage for identifying the precise amino acid position at which cisplatin exerts its inhibitory effect on $\mathrm{Na}^{+}, \mathrm{K}^{+}$-ATPase by site-directed mutagenesis.

\section{Conclusions}

This study has shown that cisplatin is capable of passively diffusing across a lipid bilayer. This can be attributed to the fact that, when stabilised in the $\left[\mathrm{PtCl}_{2}\left(\mathrm{NH}_{3}\right)_{2}\right]$ state by a high chloride concentration $(\geq 100 \mathrm{mM})$ in the surrounding medium, the drug has zero net charge. However, when the chloride concentration of the medium is reduced, the labile chloride ions can dissociate from the platinum ion, yielding positively charged complexes, i.e. first $\left[\mathrm{PtCl}\left(\mathrm{NH}_{3}\right)_{2}\left(\mathrm{OH}_{2}\right)\right]^{+}$and then $\left[\mathrm{Pt}\left(\mathrm{NH}_{3}\right)_{2}\left(\mathrm{OH}_{2}\right)_{2}\right]^{2+}$. The permeability assay results show that the rate of permeation of these species is significantly lower than that of the neutral cisplatin. These studies on unilamellar vesicles do not definitively rule out the possible contribution of active pathways to the internalisation of cisplatin or its metabolites, but indicate that passive uptake is likely to play an important role in contributing to the intracellular pool of active platinum species.

In the cytoplasm of most animal cells the chloride concentration is only approximately $4 \mathrm{mM}$, whereas in the extracellular medium it is approximately $120 \mathrm{mM} .^{34}$ Therefore, under physiological conditions one would expect a rapid passive diffusion of the neutral cisplatin into the cytoplasm of cells and a significantly slower diffusion of charged derivatives of cisplatin out of the cell. Thus, under physiological conditions the positively charged derivatives would be expected to naturally accumulate within the cytoplasm. The accumulation of cisplatin within the cytoplasm by the passive mechanism which we have just described is shown diagrammatically in Fig. 5. These results indicate that there is no absolute requirement for any proteinmediated uptake mechanism, although this doesn't exclude the 


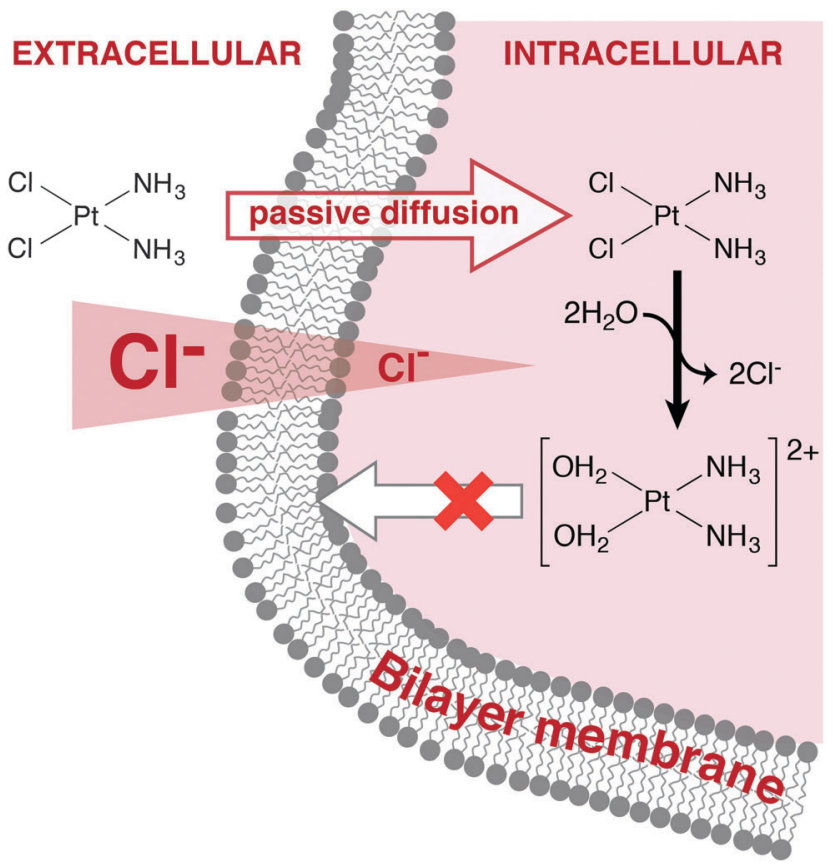

Fig. 5 Mechanism explaining the accumulation of cisplatin within the cytoplasm of cells. The neutral charge of cisplatin allows passive diffusion across the lipid phase of the cell membrane into the cytoplasm. Once within the cell the low chloride concentration causes the chloride ligands to dissociate and the complex to convert to a positively charged diaquo derivative with significantly reduced permeability.

possibility that some proteins within the cell membrane could facilitate cisplatin uptake (or extrusion).

Assuming that passive uptake of cisplatin is an important contributor to internal active platinum species, and that it occurs through the lipid phase of the membrane, then the development of resistance is unlikely to occur via a reduction in the uptake rate, since this could only come about via a change in the lipid composition of the membrane, which would be expected to have a detrimental effect on the viability of the cell. Therefore, if a reduction in drug accumulation in the cytoplasm does contribute to resistance development, this is much more likely to come about via an increase in the rate of efflux of the drug out of the cell. Evidence supporting such a mechanism has recently been presented by Tadini-Buoninsegni et al., ${ }^{35}$ who showed via electrical measurements that the copper ATPases ATP7A and ATP7B, whose normal function is to pump copper ions out of the cell, are also capable of actively pumping platinum out of a cell, with the energy provided by ATP hydrolysis. Their result provides an explanation for earlier findings that over-expression of these transporters increases resistance to cisplatin, as reviewed by Rabik and Dolan. ${ }^{36}$

The other important finding that we have reported here is that cisplatin inhibits $\mathrm{Na}^{+}, \mathrm{K}^{+}$-ATPase activity in a cellular system by acting on the enzyme's cytoplasmic face. Because the $\mathrm{Na}^{+}, \mathrm{K}^{+}$ATPase plays a crucial role in generating the $\mathrm{Na}^{+}$gradient across the membrane which provides the energy source for all amino acid and sugar transporters of the kidney, inhibition of the $\mathrm{Na}^{+}, \mathrm{K}^{+}$-ATPase would be expected to drastically impair nutrient reabsorption in the kidney and hence is likely to be in part responsible for cisplatin's nephrotoxicity. However, it should be borne in mind that the kidney is a highly sophisticated and complex organ, whose membranes contain transporters for a multitude of substrates. Therefore, it is possible that there is more than one protein in the kidney which is adversely affected by the presence of cisplatin. ${ }^{36}$

\section{Acknowledgements}

This work was supported by an NHMRC equipment grant to R.J.C. and a grant from the German Research Foundation DFG (Cluster of Excellence "Unifying Concepts in Catalysis") to T.F. and J.D. The authors thank Dr Neslihan N. Tavraz and Dr Susan Spiller for help in setting up the $\mathrm{Rb}^{+}$uptake experiments by AAS, and Dr Michael Kohl (Analytik-Service, Woltersdorf, Germany) for excellent technical support.

\section{References}

1 B. Rosenberg, Cancer Treat. Rep., 1979, 63, 1433-1438.

2 T. Hambley, J. Chem. Soc., Dalton Trans., 2001, 2711-2718.

3 K. Barabas, R. Milner, D. Lurie and C. Adlin, Vet. Comp. Oncol., 2008, 6, 1-18.

4 P. Andrews and S. Howell, Cancer Cells, 1990, 2, 35-43.

5 S. Kelleyand and M. Rozencweig, Eur. J. Cancer Clin. Oncol., 1989, 25, 1135-1140.

6 R. Perez, T. Hamilton and R. Ozols, Pharmacol. Ther., 1990, 48, 19-27.

7 H. Timmer-Bosscha, N. Mulda and E. De Vries, Br. J. Cancer, 1992, 66, 227-238.

8 R. Y. Tsang, T. Al-Fayea and H. J. Au, Drug Saf., 2009, 32, 1109-1122.

9 R. Safei, Cancer Lett., 2006, 234, 34-39.

10 A. Yonezawa and K. Inui, Biochem. Pharmacol., 2011, 81, 563-568.

11 M. D. Hall, M. Okabe, D. W. Shen, X. J. Liang and M. M. Gottesman, Annu. Rev. Pharmacol. Toxicol., 2008, 48, 495-535.

12 F. Arnesano, M. Losacco and G. Natile, Eur. J. Inorg. Chem., 2013, 2013, 2701-2711.

13 K. D. Ivy and J. H. Kaplan, Mol. Pharmacol., 2013, 83, 1237-1246.

14 M. Huličiak, J. Vacek, M. Šebala, E. Orolinová, J. Znaleziona, M. Havlíková and M. Kubala, Biochem. Pharmacol., 2012, 83, 1507-1513.

15 M. Kubala, J. Geleticova, M. Huliciak, M. Zatloukalova, J. Vacek and M. Sebala, Biomed. Pap., 2014, 158, 194-200.

16 S. C. Dhara, Indian J. Chem., 1970, 8, 193-194.

17 S. Paula, A. Volkov, A. Van Hoek, T. Haines and D. Deamer, Biophys. J., 1996, 70, 339-348.

18 A. Verkman, J. Dix and J. Seifter, Am. J. Physiol., 1985, 248, F650-F655.

19 K. L. Dürr, N. N. Tavrav, S. Spiller and T. Friedrich, J. Visualized Exp., 2013, 72, e50201. 
20 J. B. Koenderink, G. Zifarelli, L. Y. Qiu, W. Schwarz, J. J. H. H. M. De Pont, E. Bamberg and T. Friedrich, Biochim. Biophys. Acta, Biomembr., 2005, 1669, 61-68.

21 E. M. Price and J. B. Lingrel, Biochemistry, 1988, 27, 8400-8408.

22 T. Yotsuyanagi, M. Usami, Y. Noda and M. Nagata, Int. J. Pharm., 2000, 246, 95-104.

23 A. Pinto and S. Lippard, Biochim. Biophys. Acta, 1984, 780, 167-180.

24 M. S. Davies, M. D. Hall, S. J. Berners-Price and T. W. Hambley, Inorg. Chem., 2008, 47, 7673-7680.

25 F. G. Donnan, Z. Elektrochem. Angew. Phys. Chem., 1911, 17, 572-581.

26 P. A. Andrews and K. A. Albright, in Platinum and other metal coordination compounds in cancer chemotherapy, ed. S. B. Howell, Plenum, New York, 1991, pp. 151-159.

27 D. P. Gately and S. B. Howell, Br. J. Cancer, 1993, 67, 1171-1176.

28 P. A. Andrews, S. Velury, S. C. Mann and S. B. Howell, Cancer Res., 1988, 48, 68-73.
29 S. C. Mann, P. A. Andrews and S. B. Howell, Cancer Chemother. Pharmacol., 1990, 25, 236-240.

30 P. A. Andrews, S. C. Mann, H. H. Huynh and K. D. Albright, Cancer Res., 1991, 51, 3677-3681.

31 M. Shani, R. Goldschleger and S. J. D. Karlish, Biochim. Biophys. Acta, 1987, 904, 13-21.

32 L. Cheval and A. Doucet, Am. J. Physiol., 1990, 259, F111-F121.

33 M. Huličiak, L. Reinhard, M. Laursen, N. Fedosova, P. Nissen and M. Kubala, Biochem. Pharmacol., 2014, DOI: 10.1016/j.bcp.2014.08.029.

34 R. J. Clarke and X. Fan, Clin. Exp. Pharmacol. Physiol., 2011, 38, 726-733.

35 F. Tadini-Buoninsegni, G. Bartolommei, M. R. Moncelli, G. Inesi, A. Galliani, M. Sinisi, M. Losacco, G. Natile and F. Arnesano, Angew. Chem., Int. Ed., 2014, 53, 1297-1301.

36 C. A. Rabik and M. E. Dolan, Cancer Treat. Rev., 2007, 33, 9-23. 